\title{
ESTIMATION OF UV EXPOSURE IN CROATIA OVER THE SUMMER USING A SIMPLE APPROXIMATE FORMULA
}

\author{
Gordana PEHNEC ${ }^{1}$, Nenad KEZELE ${ }^{2}$, and Glenda ŠORGO² \\ Institute for Medical Research and Occupational Health ${ }^{1}$, Ruđer Bošković Institute ${ }^{2}$, Zagreb, \\ Croatia \\ Received in December 2006 \\ Accepted in July 2007
}

\begin{abstract}
The Tropospheric Ultraviolet-Visible (TUV) model, version 4.2 developed by Madronich (2003) was used to estimate the extent of ultraviolet (UV) exposure of general population in Croatia over the summer. Solar noon values (13 h local time, CEST) of the ultraviolet index (UVI) for the period April to October 2004 were calculated for 61 cities in Croatia. The results showed that the risk of sunburn at $13 \mathrm{~h}$ local time in clear weather was high between April and September (UVI >7) and very high in July (UVI >10). In July, the UVI exceeded 8 between $11 \mathrm{~h}$ and $15 \mathrm{~h}$ local time. In this study, we developed a simple approximate formula to estimate UVI. The formula includes data on the time, date, altitude and clouds. The difference between our estimate and the TUV model for the summer months of June, July and August at $10 \mathrm{~h}$ to $16 \mathrm{~h}$ local time was less than $10 \%$.
\end{abstract}

KEY WORDS: Adriatic coast, altitude, geographic position, Tropospheric Ultraviolet Visible model, UV index

Ultraviolet (UV) radiation is a part of the Sun's electromagnetic spectrum. With respect to its biological effects, the UV band of solar radiation is often divided into UV-C (100-280 nm), UV-B (280$320 \mathrm{~nm})$, and UV-A (320-400 nm) radiation. The atmosphere absorbs all UV-C and most of the UV-B radiation. In summer days, UV-B is about $5 \%$ of terrestrial UV and the rest is UV-A. However, solar UV-B causes a much greater biological damage than UV-A, contributing to about $80 \%$ of all harmful effects we associate with sun exposure. Although UV-B radiation is necessary for biological processes such as vitamin $\mathrm{D}_{3}$ synthesis, it also causes many acute and chronic conditions (1). Damages may be on the cell level (DNA damages), tissue (induction of sunburn-erythema, ageing of skin) and the whole body (skin cancers, other cancers, eye disorders, immunosuppression) $(2,3)$.
The effect of $U V$ radiation on a biological specimen is determined by spectral irradiance, $I_{\lambda}\left(\mathrm{W} \mathrm{m}^{-2} \mathrm{~nm}^{-1}\right)$ delivered to the surface of a biological body and the duration of exposure, T. Total exposure $E\left(\mathrm{~J} \mathrm{~m}^{-2}\right)$ is calculated as a time integral of the spectral irradiance according to the equation

$$
E=\int_{0}^{T} \int_{280}^{400} I_{\lambda} d \lambda d t
$$

Total exposure provides information about the total photon energy in the UV waveband falling on a unit area of the body's surface. However, the response of the biological body varies with radiation wavelength. For a given photobiological process, the wavelength dependence of the relative spectral effectiveness $S$ is the action spectrum (3). To express biological effectiveness of UV radiation at various wavelengths 
for a particular biological process it is necessary to weight spectral irradiance with the action spectrum. For a selected biological process, biologically effective UV irradiance, $I_{\text {eff }}\left(\mathrm{W} \mathrm{m}^{-2}\right)$ is

$$
I_{\text {eff }}=\sum_{280}^{400} S_{\lambda} I_{\lambda} \Delta_{\lambda}
$$

The time integral of the irradiance is called radiant exposure or radiant dose $E_{\text {eff }}\left(\mathrm{J} \mathrm{m}^{-2}\right)(3)$.

The action spectrum of McKinley and Diffey was adopted by the Commission Internationale de l'Eclairage (CIE) as the standard of average skin response over both UV-B and UV-A regions of the spectrum. The CIE (4) erythemal action spectrum for humans has been employed widely since 1987 for assessing the UV effect on human skin. Anders re-evaluated the erythemal action spectrum in 1993 (3). There are also action spectra for photoconjuctivitis and photokeratitis of the human eye (3). Human skin can adapt to UV radiation by melanin production, but eyes do not have this ability. No action spectrum for melanoma in humans is available; however Setlow et al. (5) have measured the action spectrum for melanoma in fish while De Fabo et al. (6) derived a transgenic mouse model for UV-induced melanoma. In mice overexpressing hepatocyte growth factor (HGF), exposure to UVB at neonatal age led to invasive melanomas (7). UV radiation initiates an immunosuppression which appears to be a critical event in the successful outgrowth of non-melanoma skin cancer. The photoreceptor urocanic acid, UCA, was identified through an in vivo action spectrum for immunosuppression (8).

The UV index (UVI) was proposed as a measure of the risk from UV radiation. For UVI calculation, the CIE erythemal action spectrum is suggested, because sunburn is the most common harmful effect on human skin. The UV index is defined as the integral over wavelengths of the solar spectral irradiance reaching the earth's surface, weighted by the erythema action spectrum. It usually refers to the solar noon value of the dose rate for cloudless days. According to the US EPA, UVI (9) is divided in the following categories:

$\begin{array}{ll}0-2 & \text { minimal } \\ 3-4 & \text { low } \\ 5-6 & \text { moderate } \\ 7-9 & \text { high } \\ 10 \text { and more } & \text { very high }\end{array}$

Spectral irradiance is usually measured using spectroradiometers. Total irradiance can be measured with a broadband radiometer over a selected waveband. Passive dosimeters such as polysulphone dosimeter are also in use. Instruments for measuring spectral irradiance are complex and difficult to maintain. Due to high cost and problems with calibration, UV measurements are still relatively rare $(2,3)$.

Instead, UV exposure is frequently estimated using different mathematical models. Surface UV radiation is a function of the extraterrestrial solar flux, solar zenith angle, ozone amount, cloud characteristic, aerosols and surface albedo. Models for UV-index forecasting usually include in calculation the following parameters: geographic position (longitude, latitude and altitude), date, time of the day, total ozone data and cloud data, and, when available, aerosol data.

Although the harmful effects of UV radiation are well established and described in literature $(1,3,6)$, measurements in Croatia are limited. In Zagreb, the measurements of erythemal UV radiation started in 1998 (10). Values of UVI higher than 10 were observed occasionally in the summer (11). UVI forecasts using the Model DM4 are available on the web pages of the Meteorological and Hydrological Service of Croatia (12). There are only a few papers describing solar UV exposure in Croatia $(10,11,13)$. The aim of this study was to estimate the extent of UV exposure of Croatian general population using a radiative transfer model known as the Tropospheric Ultraviolet-Visible Model (TUV). It calculates UV indices for different places on different dates and times throughout the year, taking into account their location, atmospheric conditions, and geophysical constants. Because these values are especially interesting over the summer and on the Adriatic coast where people spend a lot of time outdoors at this time of the year, we wanted to develop a simple approximate formula, based on more accurate results obtained by the TUV model, that would make possible a reliable estimate for any location in Croatia, time, and weather condition over the three summer months of June, July and August.

\section{METHODS}

To evaluate UV exposure we used the Tropospheric Ultraviolet-Visible Model (TUV), version 4.2 (developed by Sasha Madronich; released in May 2003) (14-17). TUV is a multi-stream radiative transfer model able to quantify the transfer of radiation in a scattering and absorbing atmosphere. Atmospheric curvature 
(important for low sun conditions) is modelled using a pseudo-spherical approximation. It is a one-dimensional FORTRAN 77 model suitable to compute various radiative quantities over a broad range of environmental conditions. It can be used in the wavelength range $121 \mathrm{~nm}$ to $750 \mathrm{~nm}$ for calculating the spectral irradiance, the spectral actinic flux, photodissociation coefficients, and biological effective irradiance. Output parameters are presented as functions of wavelength and altitude. Many papers describe good agreement between measured values of UV radiation and values calculated by TUV (18-20).

In our first approximation, the following constants and atmospheric conditions were assumed:

- US standard atmosphere (21)

- surface albedo 0.1 at all wavelengths

- aerosol vertical optical depth $\mathrm{T}_{\text {aer }}=0.235$ at 550 $\mathrm{nm}$ from surface to space [for aerosols, vertical profile typical for continental regions from Elterman (22) was assumed]

- total ozone column 300 DU (DU - Dobson Unit, one $\mathrm{DU}$ is $2.69 \times 10^{20}$ ozone molecules per square meter)
- to calculate the dose rate, the UV spectrum on the ground was integrated with a $1 \mathrm{~nm}$ step over the $280 \mathrm{~nm}$ to $420 \mathrm{~nm}$ band

- solar noon time

Dose rates and UV indices were calculated for 61 sites in Croatia (Figure 1) with corresponding data on longitude, latitude and altitude. We selected the city of Makarska as a representative location for estimating the effects of elevation, time of the day, cloudiness and total ozone column because it is at the sea level, it is central at the Croatian coast, it is at the feet of Mt Biokovo (1762 m a. s. l.), and it has the clearest sky all over the year. UV indices were calculated for different days at $13 \mathrm{~h}$ local time (Central European Summer Time, CEST), which roughly corresponds to solar noon. For 1 July, UVI were calculated for different daytime hours in order to establish their dependence on the time of the day. Clear sky was assumed in most calculations. When considering the effect of clouds on UV indices, we assumed a uniform cloud coverage of the sky. The input parameter was cloud optical depth, $\mathrm{T}$.

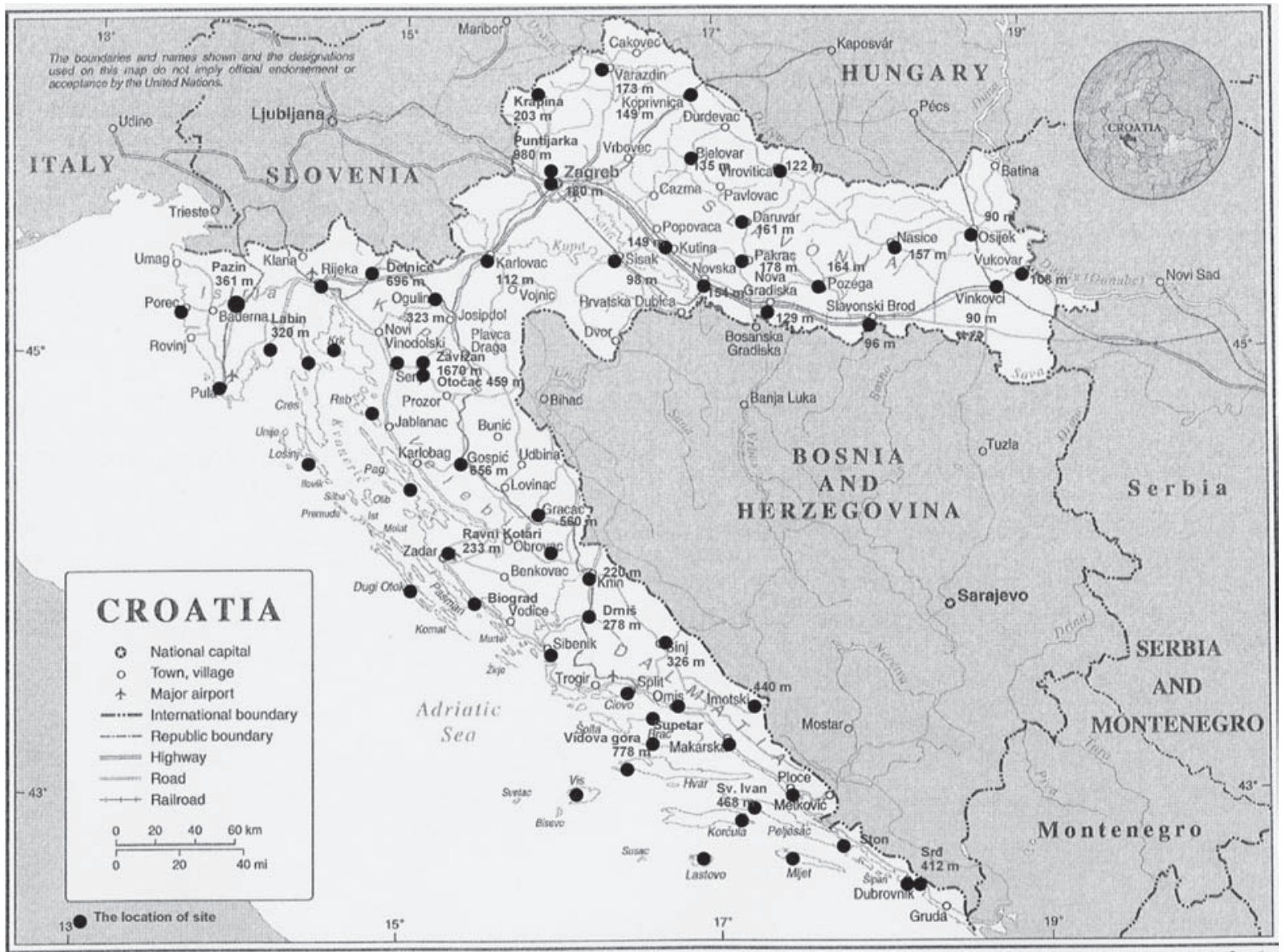

Figure 1 The location of 61 Croatian sites with UVI calculated using the TUV model 
Table 1 (IVI calculated by TUV for 61 sites in Croatia at $13 \mathrm{~h}$ local time (CEST) for three different days

\begin{tabular}{|c|c|c|c|c|}
\hline & Site & April, 1 & July, 1 & October, 1 \\
\hline 1 & Biograd & 6.6 & 10.5 & 4.7 \\
\hline 2 & Bjelovar & 6.2 & 10.2 & 4.2 \\
\hline 3 & Cres & 6.4 & 10.3 & 4.4 \\
\hline 4 & Daruvar & 6.3 & 10.2 & 4.3 \\
\hline 5 & Delnice & 6.5 & 10.5 & 4.5 \\
\hline 6 & Drniš & 6.7 & 10.6 & 4.7 \\
\hline 7 & Dubrovnik & 6.9 & 10.7 & 4.9 \\
\hline 8 & Gospić & 6.7 & 10.7 & 4.7 \\
\hline 9 & Gračac & 6.7 & 10.7 & 4.7 \\
\hline 10 & Hvar & 6.9 & 10.7 & 4.9 \\
\hline 11 & Imotski & 6.9 & 10.8 & 4.8 \\
\hline 12 & Karlovac & 6.3 & 10.2 & 4.3 \\
\hline 13 & Knin & 6.7 & 10.6 & 4.7 \\
\hline 14 & Komiža & 6.9 & 10.7 & 4.8 \\
\hline 15 & Koprivnica & 6.1 & 10.1 & 4.2 \\
\hline 16 & Korčula & 6.9 & 10.7 & 4.8 \\
\hline 17 & Krapina & 6.1 & 10.2 & 4.2 \\
\hline 18 & Krk & 6.4 & 10.3 & 4.4 \\
\hline 19 & Kutina & 6.3 & 10.3 & 4.3 \\
\hline 20 & Labin & 6.4 & 10.4 & 4.5 \\
\hline 21 & Lastovo & 6.9 & 10.7 & 4.9 \\
\hline 22 & Lipik & 6.3 & 10.3 & 4.3 \\
\hline 23 & M. Lošinj & 6.5 & 10.4 & 4.5 \\
\hline 24 & Makarska & 6.8 & 10.6 & 4.8 \\
\hline 25 & Našice & 6.3 & 10.2 & 4.3 \\
\hline 26 & Nova Gradiška & 6.3 & 10.3 & 4.3 \\
\hline 27 & Ogulin & 6.4 & 10.4 & 4.4 \\
\hline 28 & Omiš & 6.8 & 10.6 & 4.7 \\
\hline 29 & Osijek & 6.2 & 10.2 & 4.2 \\
\hline 30 & Otočac & 6.3 & 10.3 & 4.3 \\
\hline 31 & Pag & 6.5 & 10.4 & 4.5 \\
\hline 32 & Pakrac & 6.3 & 10.3 & 4.3 \\
\hline 33 & Pazin & 6.4 & 10.4 & 4.4 \\
\hline 34 & Ploče & 6.9 & 10.7 & 4.8 \\
\hline 35 & Poreč & 6.3 & 10.2 & 4.4 \\
\hline 36 & Požega & 6.3 & 10.3 & 4.3 \\
\hline 37 & Pula & 6.3 & 10.3 & 4.5 \\
\hline 38 & Puntijarka & 6.4 & 10.6 & 4.4 \\
\hline 39 & Rab & 6.4 & 10.3 & 4.5 \\
\hline 40 & Ravni Kotari & 6.7 & 10.6 & 4.7 \\
\hline 41 & Rijeka & 6.3 & 10.2 & 4.3 \\
\hline 42 & Sali & 6.6 & 10.5 & 4.7 \\
\hline 43 & Senj & 6.4 & 10.3 & 4.4 \\
\hline 44 & Sinj & 6.8 & 10.7 & 4.8 \\
\hline 45 & Sisak & 6.3 & 10.2 & 4.3 \\
\hline 46 & Slavonski Brod & 6.3 & 10.3 & 4.3 \\
\hline 47 & Sobra (Mljet) & 6.9 & 10.7 & 4.9 \\
\hline 48 & Split & 6.7 & 10.6 & 4.7 \\
\hline 49 & Srđ & 7.1 & 10.9 & 5.0 \\
\hline 50 & Ston & 6.9 & 10.7 & 4.9 \\
\hline 51 & Supetar & 6.8 & 10.6 & 4.8 \\
\hline 52 & Sv. Ivan (Pelješac) & 7.0 & 10.9 & 5.0 \\
\hline 53 & Šibenik & 6.7 & 10.5 & 4.7 \\
\hline 54 & Varaždin & 6.1 & 10.1 & 4.1 \\
\hline 55 & Vidova gora (Brač) & 7.0 & 11.0 & 5.0 \\
\hline 56 & Vinkovci & 6.3 & 10.2 & 4.3 \\
\hline 57 & Virovitica & 6.2 & 10.2 & 4.2 \\
\hline 58 & Vukovar & 6.3 & 10.2 & 4.3 \\
\hline 59 & Zadar & 6.6 & 10.5 & 4.6 \\
\hline 60 & Zagreb & 6.2 & 10.2 & 4.3 \\
\hline 61 & Zavižan & 6.9 & 11.1 & 4.8 \\
\hline
\end{tabular}

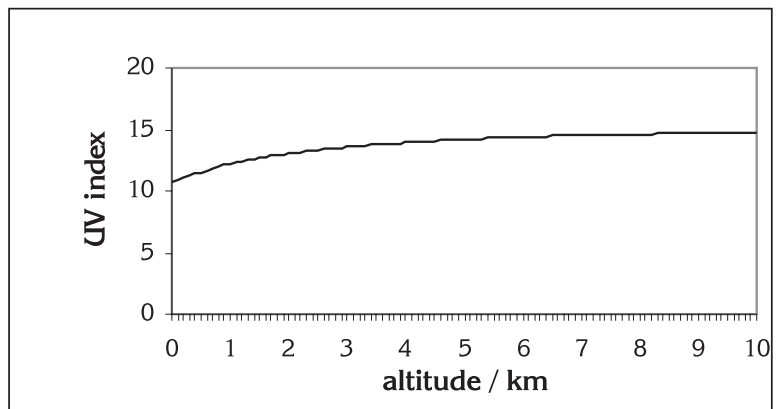

Figure 2 Annual variations of IVI (calculated for Makarska at $13 \mathrm{~h}$ local time, in clear weather

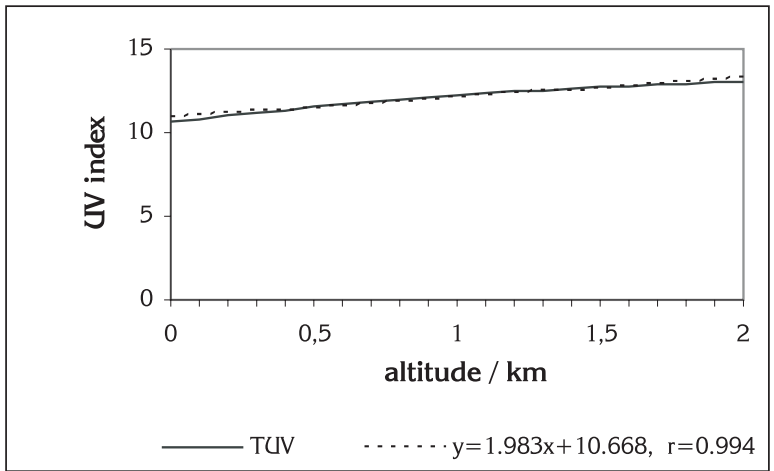

Figure 3 Changes in (IVI with altitude; up to $10 \mathrm{~km}$ (upper graph) and up to $2 \mathrm{~km}$ (lower graph), calculated for Makarska on 1 July, in clear weather

For UV index estimation some simplified equations were found and compared with the TUV results. These equations explain the changes in UVI with daytime, elevation, cloudiness, and the time of the year, and will be discussed in the section below.

\section{RESULTS}

UV indices were calculated for 61 sites in Croatia (Figure 1). All values were calculated for $13 \mathrm{~h}$ local time (daylight saving time, CEST), which corresponds roughly to an actual solar noon time. Table 1 shows UVI under clear sky for three days set three months apart: 1 April, 1 July, and 1 October. They range between 6.1 and 7.1 in April, 10.1 and 11.1 in July, and 4.1 and 5.0 in October. The maximum UVI, 11.13, was calculated for Zavižan (1670 m a.s.l.) in July. However, as the extreme east and west points in Croatia have different solar zenith angles (SZA), actual UVI may differ as well. In order to estimate this error, UVI was calculated for extreme east and west Croatian towns, Vukovar and Poreč, respectively, which are approximately at the same latitude. For better comparison, the same altitude ( $0 \mathrm{~m}$ a.s.l.) was taken 
Table 2 Differences in solar zenith angle (SZA) and (IVI for two sites with the same latitude $\left(45.3^{\circ} \mathrm{N}\right.$ ) and greater difference in longitude (calculated for 1 July; altitude $0 \mathrm{~km}$ a.s.l.)

\begin{tabular}{|c|c|c|c|c|c|c|}
\hline \multirow[b]{2}{*}{$\begin{array}{l}\text { Local } \\
\text { time / h }\end{array}$} & \multicolumn{3}{|c|}{ SZA } & \multicolumn{3}{|c|}{ UV index } \\
\hline & $\begin{array}{c}\text { Vukovar } \\
19.007{ }^{\circ} \mathrm{E}\end{array}$ & $\begin{array}{c}\text { Poreč } \\
13.593^{\circ} \mathrm{E}\end{array}$ & Difference & $\begin{array}{c}\text { Vukovar } \\
19.007^{\circ} \mathrm{E}\end{array}$ & $\begin{array}{c}\text { Poreč } \\
13.593^{\circ} \mathrm{E}\end{array}$ & Difference \\
\hline 10 & 40.55 & 44.21 & 3.66 & 6.07 & 5.22 & 0.85 \\
\hline 13 & 22.36 & 22.31 & 0.05 & 10.19 & 10.20 & 0.01 \\
\hline 16 & 44.66 & 41.00 & 3.66 & 5.12 & 5.97 & 0.85 \\
\hline
\end{tabular}

Table 3 Correlation coefficients between UVI calculated by TUV for different months

\begin{tabular}{ccccccc}
\hline & May & Jun & Jul & Aug & Sept & Oct \\
\hline April & 0.99 & 0.97 & 0.97 & 0.99 & 0.99 & 0.99 \\
May & & 0.99 & 0.99 & 0.99 & 0.99 & 0.98 \\
Jun & & & 0.99 & 0.99 & 0.98 & 0.95 \\
Jul & & & & 0.99 & 0.98 & 0.96 \\
Aug & & & & & 0.99 & 0.98 \\
Sep & & & & & & 0.99 \\
\hline
\end{tabular}

Table 4 Linear regression parameters for the dependence of UVI on altitude (up to $2 \mathrm{~km}$ a.s.l.).

\begin{tabular}{ccccc}
\hline Month & Slope & Intercept & $\mathrm{R}$ & $\begin{array}{c}\text { Difference } \\
\text { UVI }(2 \mathrm{~km}) \text { - UVI (0 km) }\end{array}$ \\
\hline Jan & 0.366 & 1.383 & 0.996 & 0.8 \\
Feb & 0.566 & 2.192 & 0.996 & 1.1 \\
Mar & 0.960 & 4.038 & 0.995 & 1.9 \\
April & 1.446 & 6.821 & 0.995 & 2.8 \\
May & 1.797 & 9.216 & 0.995 & 3.6 \\
Jun & 1.968 & 10.531 & 0.995 & 4.0 \\
Jul & 1.982 & 10.668 & 0.995 & 3.9 \\
Aug & 1.853 & 9.677 & 0.995 & 3.7 \\
Sep & 1.542 & 7.483 & 0.995 & 3.1 \\
Oct & 1.099 & 4.797 & 0.995 & 2.2 \\
Nov & 0.648 & 2.550 & 0.996 & 1.3 \\
Dec & 0.396 & 1.500 & 0.996 & 0.8 \\
\hline
\end{tabular}

in calculations. Table 2 shows the differences between the two towns calculated for 1 July, $10 \mathrm{~h}, 13 \mathrm{~h}$, and $16 \mathrm{~h}$ local time, indicating that the effect is mostly pronounced in the morning and afternoon hours and is negligible at noon time.

Correlation coefficients were calculated between UVI for different months at every location. Table 3 shows correlation coefficients between UVI calculated for the period April-October.

Annual variations of UVI for Makarska are shown in Figure 2. It also shows a comparison between TUV calculations and calculations according to the simplified equation

$$
\text { UIVI }=11-\left|\frac{w-25}{4}\right|
$$

where $w$ is the week of the year. The difference between UVI calculated by TUV and by equation

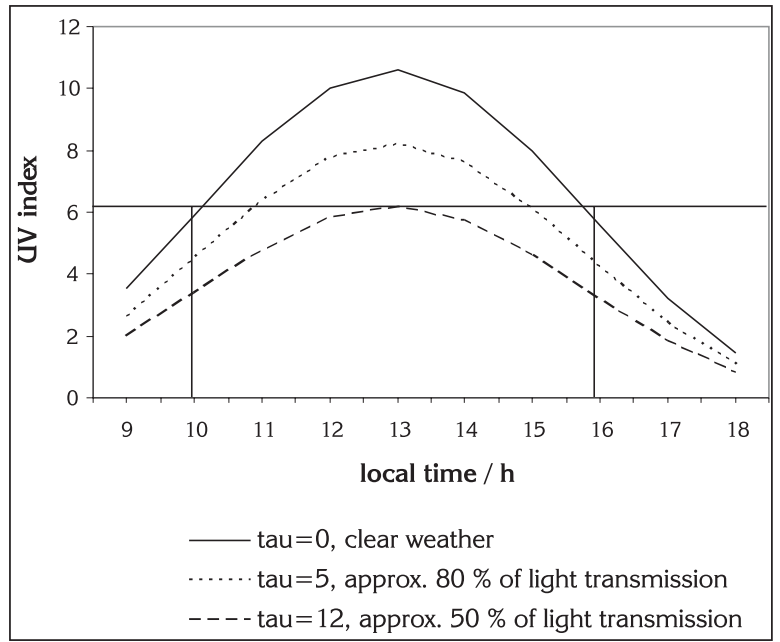

Figure 4 Diurnal variations of UVI in clear weather (cloud optical depth, $T=0)$, and cloudy weather ( $T=5$ and $T=12)$, calculated for Makarska on 1 July 
Table 5 Differences between TIV and equation [5]* results in the estimation of UVI changes with altitude

\begin{tabular}{|c|c|c|c|c|c|c|c|c|c|c|c|c|}
\hline $\begin{array}{l}\text { Month } \\
\text { Week }\end{array}$ & \multicolumn{3}{|c|}{$\begin{array}{c}5 \\
17 \\
\end{array}$} & \multicolumn{3}{|c|}{$\begin{array}{c}6 \\
22 \\
\end{array}$} & \multicolumn{3}{|c|}{$\begin{array}{c}7 \\
26 \\
\end{array}$} & \multicolumn{3}{|c|}{$\begin{array}{c}8 \\
31 \\
\end{array}$} \\
\hline & \multicolumn{2}{|c|}{ UVI } & & \multicolumn{2}{|c|}{ UVI } & & \multicolumn{2}{|c|}{ UVI } & \multicolumn{4}{|c|}{ UVI } \\
\hline $\begin{array}{c}\text { Altitude / } \\
\text { km }\end{array}$ & TUV & [5] & $\mathrm{D} / \% * *$ & TUV & [5] & $\mathrm{D} / \%$ & TUV & [5] & $\mathrm{D} / \%$ & TUV & [5] & $\mathrm{D} / \%$ \\
\hline 0 & 9.0 & 9.0 & 0.2 & 10.3 & 10.3 & 0.6 & 10.5 & 10.8 & -2.9 & 9.5 & 9.5 & -0.3 \\
\hline 0.1 & 9.3 & 9.2 & 0.8 & 10.6 & 10.4 & 1.2 & 10.7 & 10.9 & -2.3 & 9.7 & 9.7 & 0.3 \\
\hline 0.2 & 9.5 & 9.4 & 1.2 & 10.8 & 10.6 & 1.7 & 11.0 & 11.1 & -1.8 & 9.9 & 9.9 & 0.8 \\
\hline 0.3 & 9.7 & 9.5 & 1.6 & 11.1 & 10.8 & 2.1 & 11.2 & 11.3 & -1.3 & 10.2 & 10.1 & 1.2 \\
\hline 0.4 & 9.9 & 9.7 & 2.0 & 11.3 & 11.0 & 2.5 & 11.5 & 11.5 & -0.8 & 10.4 & 10.2 & 1.5 \\
\hline 0.5 & 10.1 & 9.9 & 2.4 & 11.5 & 11.2 & 2.8 & 11.7 & 11.7 & -0.4 & 10.6 & 10.4 & 1.9 \\
\hline 0.6 & 10.4 & 10.1 & 2.6 & 11.8 & 11.4 & 3.2 & 11.9 & 11.9 & -0.1 & 10.9 & 10.6 & 2.2 \\
\hline 0.7 & 10.6 & 10.3 & 2.8 & 12.0 & 11.6 & 3.4 & 12.2 & 12.1 & 0.2 & 11.1 & 10.8 & 2.5 \\
\hline 0.8 & 10.8 & 10.4 & 3.1 & 12.2 & 11.8 & 3.7 & 12.4 & 12.3 & 0.5 & 11.3 & 11.0 & 2.7 \\
\hline 0.9 & 11.0 & 10.6 & 3.3 & 12.5 & 12.0 & 3.8 & 12.6 & 12.5 & 0.7 & 11.5 & 11.2 & 2.9 \\
\hline 1 & 11.2 & 10.8 & 3.5 & 12.7 & 12.2 & 4.1 & 12.8 & 12.7 & 0.9 & 11.7 & 11.4 & 3.1 \\
\hline 1.1 & 11.3 & 11.0 & 3.2 & 12.9 & 12.4 & 3.8 & 13.0 & 12.9 & 0.7 & 11.9 & 11.5 & 2.7 \\
\hline 1.2 & 11.5 & 11.2 & 2.8 & 13.0 & 12.6 & 3.5 & 13.2 & 13.1 & 0.4 & 12.0 & 11.7 & 2.5 \\
\hline 1.3 & 11.6 & 11.3 & 2.5 & 13.2 & 12.8 & 3.2 & 13.3 & 13.3 & 0.1 & 12.2 & 11.9 & 2.2 \\
\hline 1.4 & 11.8 & 11.5 & 2.2 & 13.3 & 12.9 & 3.0 & 13.5 & 13.5 & -0.2 & 12.3 & 12.1 & 1.9 \\
\hline 1.5 & 11.9 & 11.7 & 1.8 & 13.5 & 13.1 & 2.6 & 13.7 & 13.7 & -0.5 & 12.5 & 12.3 & 1.6 \\
\hline 1.6 & 12.1 & 11.9 & 1.6 & 13.7 & 13.3 & 2.3 & 13.8 & 13.9 & -0.7 & 12.6 & 12.5 & 1.3 \\
\hline 1.7 & 12.2 & 12.1 & 1.2 & 13.8 & 13.5 & 2.1 & 14.0 & 14.1 & -1.0 & 12.8 & 12.6 & 0.9 \\
\hline 1.8 & 12.4 & 12.2 & 0.9 & 14.0 & 13.7 & 1.8 & 14.1 & 14.3 & -1.2 & 12.9 & 12.8 & 0.6 \\
\hline 1.9 & 12.5 & 12.4 & 0.6 & 14.1 & 13.9 & 1.5 & 14.3 & 14.5 & -1.6 & 13.1 & 13.0 & 0.3 \\
\hline 2 & 12.6 & 12.6 & 0.2 & 14.3 & 14.1 & 1.2 & 14.4 & 14.7 & -1.8 & 13.2 & 13.2 & 0.0 \\
\hline
\end{tabular}

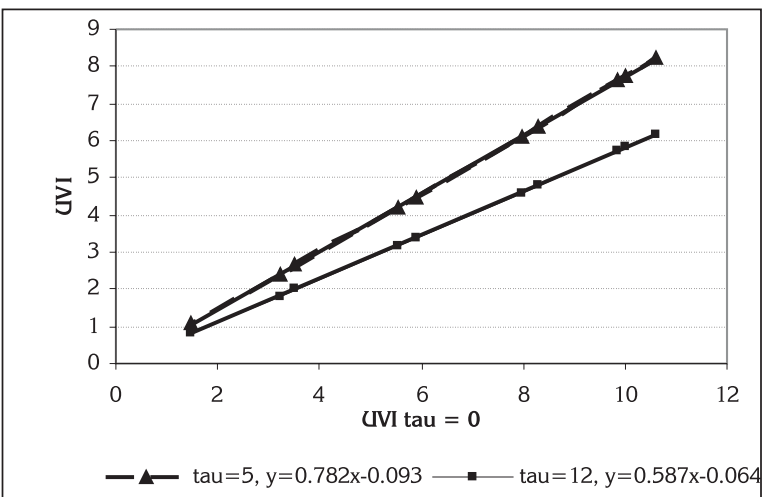

Figure 5 The comparison of UVI in clear and cloudy weather

[3] was calculated as an error (\%) according to the equation [4], and it ranged between $0.21 \%$ and $2.87 \%$, except for April and September, when it was $18 \%$.

$$
D=\frac{\operatorname{UVI}(T U N)-U V I(e q)}{U V I(T U V)} \times 100
$$

The influence of elevation on UVI was evaluated for Makarska. Figure 3 shows changes in UVI with altitude

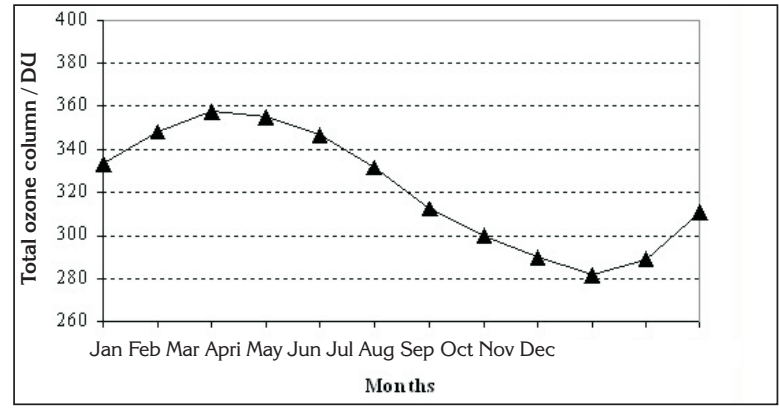

Figure 6 Annual variations of total ozone column calculated with monthly averages over the period 1996-2005

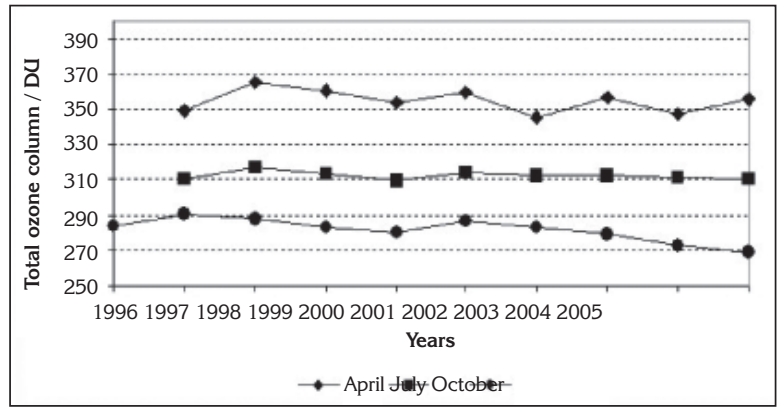

Figure 7 Variations in total ozone column for the months of April, July and October over the period 1996-2005 
Table 6 Estimated diurnal (IVI variation using the TUV model and equation [6]*

\begin{tabular}{|c|c|c|c|}
\hline \multirow[b]{2}{*}{ Local time / $\mathrm{h}$} & \multicolumn{2}{|c|}{ UVI } & \multirow{2}{*}{$\begin{array}{l}\text { Error } \\
\text { D / \% }\end{array}$} \\
\hline & TUV & [6] & \\
\hline 9 & 3.5 & 4.3 & -23.4 \\
\hline 10 & 5.9 & 6.0 & -1.9 \\
\hline 11 & 8.3 & 7.7 & 7.4 \\
\hline 12 & 10.0 & 9.3 & 6.8 \\
\hline 13 & 10.6 & 11.0 & -3.9 \\
\hline 14 & 9.8 & 9.3 & 5.1 \\
\hline 15 & 8.0 & 7.7 & 3.8 \\
\hline 16 & 5.5 & 6.0 & -8.1 \\
\hline 17 & 3.2 & 4.3 & -34.9 \\
\hline
\end{tabular}

Table 7 Correction of (IVI with regard to changes in total ozone column (equation [9]*) for Makarska at $13 \mathrm{~h}$ local time

\begin{tabular}{cccc}
\hline Month & $\begin{array}{c}\text { Average total } \\
\text { ozone column / DU }\end{array}$ & UVI (300) & $\begin{array}{c}\text { UVI (DU) estimated by } \\
\text { equation [9] }\end{array}$ \\
\hline April & 354.7 & 6.8 & 5.7 \\
July & 312.2 & 10.6 & 10.2 \\
October & 281.5 & 4.8 & 5.2 \\
\hline
\end{tabular}

on 1 July, under the clear sky. For altitudes below 2000 $\mathrm{m}$ the altitude-dependence curve is almost linear, and may be described by linear regression. Table 4 shows parameters of linear regression lines for every month of the year. This makes it possible to expand equation [3] to the estimation of UVI at different altitudes. Equation [5] applies for the months of May through August.

$$
\text { UVI }=\left(2-\left|\frac{w-25}{40}\right| \times h+\left(11-\left|\frac{w-25}{4}\right|\right)\right.
$$

where $w$ stands for the week of the year and $h$ for altitude expressed in $\mathrm{km}$. Values obtained by equation [5] were compared with corresponding values from the TUV model (Table 5).

Figure 4 shows diurnal variations of UVI on 1 July, calculated by TUV for different cloud conditions in Makarska. Under different cloudiness, UVI indices may be represented as a linear function of UVI under clear-sky conditions (Figure 5).

Diurnal variations of UVI were calculated according to equation [6]:

$$
U V I=11-\left|\frac{t-13}{0.6}\right|
$$

where $t$ is local time (h).

The comparison of UVI calculated by TUV and by equation [6] is shown in Table 6.

\section{DISCUSSION}

In our study, UVI (Table 1) was calculated for $13 \mathrm{~h}$ local time. However, there is a difference between the SZA at the extreme east and west points of the country (Table 2). Differences are significant at $10 \mathrm{~h}$ and $16 \mathrm{~h}$ local time, as the UVI curve (Figure 4) has the greatest slope at these hours. As the differences are minimal at $13 \mathrm{~h}$ (top of the curve), the error between (IVI may be neglected.

Calculations of UVI (Table 1) show that even in April there is a moderate risk of sunburn from UV radiation in clear weather (UVI between 6 and 7), which turns to high and very high risk in July (UVI above 10). Figure 2 shows that the risk of sunburn at $13 \mathrm{~h}$ local time is high between May and September (UVI >7). In July, the calculated UVI in Makarska was above 8 between $11 \mathrm{~h}$ and $15 \mathrm{~h}$ local time (Figure 4). Recommendations are (9) to limit outdoor activities at this time of the day, and to use protection against sunburns (a hat and other clothing, sunglasses, or sunscreen).

Correlation coefficients were calculated between solar noon UVI at each location for the period April-October (Table 3). There is a significant linear correlation between UVI calculated for different months. These results show that UVI variations over the year may be estimated using simple linear regression. 
We estimated the annual UVI using equation [3], and compared it to the TUV results. For Makarska, we obtained a good agreement between equation [3] and the TUV results for the period May-August, with an error of less than $3 \%$. For April and September there was a greater difference between the results (up to $18 \%$ ).

UVI increases significantly with altitude (Figure 3). Below $2 \mathrm{~km}$ a.s.l., and the maximum altitude in Croatia is $1831 \mathrm{~m}$ a.s.l. (Mt Dinara), the curve is almost linear and may be described by linear regression. The dependence is linear in all months over the year, but the slope and intercept vary significantly (Table 4). According to the literature, a UVI increase of $6 \%$ per $\mathrm{km}$ is expected (10). For more accurate estimation, we used equation [5]. Table 5 shows that there is no significant difference between the TUV results and results obtained by our simplified equation [5]. The error was less than $4 \%$ for May-August and for all altitudes (being below $2 \mathrm{~km}$ a.s.l.).

The estimation of diurnal UV variation using equation [6] showed that this equation also gave a good agreement with the TUV model (Table 6). The error was less than $8 \%$ for local time between $10 \mathrm{~h}$ and $16 \mathrm{~h}$, when UVI may have been increased (Figure 4).

Clouds significantly reduce UV exposure (Figure 4). Those with a $50 \%$ transmission of light reduce UVI by more than $50 \%$. There is a linear relationship between UVI calculated in clear weather and UVI in cloudy weather (Figure 5). If the intercept is zero, the UVI can be parameterized by a simple equation:

$\mathrm{UVI}=\mathrm{UVI}_{0} \times \mathrm{C}$

where $\mathrm{UVI}_{0}$ is the clear-sky $\mathrm{UVI}$ and $C$ is a cloud transmission factor with values $0-1$. These results correspond to those found in literature $(16,20)$.

An estimation of UVI may use a summarised formula which includes data on the week of the year, time, altitude and cloudiness. Therefore we added equations [6] and [7] to equation [5] to make one comprehensive equation:

$U V I=\left[\left(11-\left|\frac{t-13}{0.6}\right|\right)+\left(11-\left|\frac{w-25}{4}\right|\right)+\left(2-\left|\frac{w-25}{40}\right| \times h\right)\right] \times C$

This equation was used to estimate UVI for the period between May and August, from $10 \mathrm{~h}$ to $16 \mathrm{~h}$ local time, and for altitudes up to $2 \mathrm{~km}$ a.s.l.

The influence of total ozone column was also studied. In Croatia, annual averages of total ozone column varied from 351.7 DU in 1979 to 316.8 in 1992, and the 25-year average (1979-2004) was 332.5
DU (23). The decrease in total ozone was about $6 \%$ during the same 25-year period, but in the last six years the decrease was only $2 \%(23,24)$. Total ozone column values were higher in the spring and summer (11). Figure 6 presents annual variations of total ozone column over the last decade. Average monthly ozone amounts were calculated for the period 1996-2005. The ozone data were obtained from the NASA/TOMS web site (25). Figure 7 shows variations of average ozone values for months April, July and October over the same decade.

UVI was calculated by TUV for Makarska on 1 July, with the following ozone column values: 250 , 270, 300, 330 and 350 DU. Changes in ozone were found to contribute significantly to UVI (according to our calculations, a $10 \%$ decrease in ozone column corresponded to a $11 \%$ to $13 \%$ increase in (UVI). These results correspond to the literature data, where a decrease of $1 \%$ in total ozone column corresponds to a $1.1 \%$ increase in UVI (26). Influence of changes in total ozone column on UV exposure was discussed in detail by Micheletti et al. (26). They calculated radiation amplification factor (RAF) with the TUV model for different action spectra. RAF is a measure of the sensitivity of biologically active irradiadiance, $I_{b i o}$, to changes in ozone vertical column amount. A simple parameterization of the dependence of UVI on ozone is as follows:

$$
\frac{U V I(D U)}{U V I(300)}=\left(\frac{300}{D U}\right)^{R A F}
$$

where DU is ozone amount in Dobson Units and RAF is Radiation Amplification Factor, which for erythema action spectrum is about 1.1 (26).

However, unlike other data relevant for UVI calculation, the Internet data on ozone concentrations are available with a delay of a day or two. For that reason we did not include stratospheric ozone data in our approximate formula. The same total ozone column was used in all calculations, because we wanted to separate geographic position and time data (which are easy available to general population) from other influences. Over the summer months, while the highest UVI are obtained (June to August), total ozone values are usually higher than 300 DU which is used in our calculations (Figures 6 and 7). This is why our estimated UVI may be equal or higher than real. The idea is to avoid surprise on days with lower stratospheric ozone values that would lead an increased number of sunburns. However, all our data may be corrected by ozone amount using equation 
[9]. Table 7 shows corrections for Makarska in the months of April, July, and October.

\section{CONCLUSION}

Our estimation of UV exposure in Croatia over one year has taken into account the influence of geographic position, altitude, time of the day, time of the year, and clouds. We established some linear relations between them and UVI. This made it possible for us to develop a simplified, Croatia-specific formula to quickly estimate UV exposure over the summer. Unlike the TUV model, our formula does not include variations of tropospheric pollutants, stratospheric ozone, aerosols and albedo. Our future research will focus on a detailed estimation of UV exposure and influence of sunlight on photochemical processes.

\section{Acknowledgement}

We wish to thank Dr Sasha Madronich from The Nacional Center for Atmospheric Research, Boulder, Colorado, for advices and correction of the manuscript. We are also grateful to Dr Julia Lee-Taylor (NCAR, Boulder, CO) for helping us with the TUV model. Special thanks goes to Professor Leo Klasinc for helpful suggestions during the preparation of the manuscript.

\section{REFERENCES}

1. Diffey BL. Ultraviolet radiation and human health. Clin Dermatol 1998;16:83-9.

2. Diffey BL. Sources and measurement of ultraviolet radiation. Methods 2002;28:4-13.

3. Wong JCF, Parisi AV. Assessment of ultraviolet radiation exposures in photobiological experiments [displayed 17 November 2006]. Available at http://www.photobiology. com/UVR98/wongrev/index.htm

4. International Commission on Illumination (CIE). A reference action spectrum for ultraviolet induced erythema in human skin. Research note. CIE J 1987;6:17-22.

5. Setlow RB, Grist E, Thompson K, Woodhead AP. Wavelengths effective in induction of malignant melanoma. Proc Natl Acad Sci 1993;90:6666-70.

6. De Fabo EC. Initial studies on an in vivo action spectrum for melanoma induction, review. Progr Biophys Molec Biol 2006;92:97-104.

7. Noonan FP, Dudek J, Merlino G, De Fabo EC. Animal models of melanoma: An HGF/SF transgenic mouse model may facilitate experimental access to TV initiating events. Pigment Cell Res 2003;16:16-25.

8. De Fabo EC, Noonan FP. Mechanism of immune suppression by ultraviolet irradiation in vivo. I. Evidence for the existence of a unique photoreceptor in skin and its role in photoimmunology. J Exp Med 1983;158:8498.

9. United States Environmental Protection Agency (US EPA). Stay Healthy in the Sun, information about UV radiation for meteorologists. Washington: US EPA; 1998.

10. Lisac I. Sunčevo zračenje i UV indeks [Solar UV radiation and UV index, in Croatian]. Gospodarstvo i okoliš 1998;23:381-4.

11. Vujnović V, Lisac I. Prostiranje Sunčeva zračenja kroz atmosferu i eritemalno učinkovito ultraljubičasto zračenje u Hrvatskoj [Solar radiation transfer through the atmosphere and erythermally effective UV radiation in Croatia, in Croatian]. In: Ivanišević G, editor. Zbornik radova sa skupa Zdravstveni turizam u Hrvatskoj; 7-9 Sept 2001; Veli Lošinj. Zagreb: AMZH; 2001. p. 13946.

12. Meteorological and Hydrological Service [displayed 30 April 2007]. Available at http://meteo.hr/index en.php

13. Lisac I, Vujnović V. Atmosferski ozon i Sunčevo UV zračenje nad područjem Hrvatske [Atmospheric ozone and solar UV radiation over Croatia, in Croatian]. In: Stilinović B, Pepeljnjak S, editors. Zbornik radova II hrvatskog simpozija s međunarodnim sudjelovanjem "Aromaterapija i biljni lijekovi u zdravstvenoj ponudi Hrvatske"; 26-28 Sept 2000; Opatija. Ičići: Revelin; 2001. p. 145-54.

14. Tropospheric Ultraviolet Visible Model [displayed 17 November 2006]. Available at http://cprm.acd.ucar. edu/Models/TUV/index.shtml

15. Madronich S, Flocke SJ. The role of solar radiation in atmospheric chemistry. In: Boule P, editor. Handbook of environmental chemistry. Heidelberg: Springer-Verlag; 1998. p. 1-26.

16. Weatherhead EC. Report on geographic and seasonal variability of UV affecting human and ecological health. Task Report, Contract 4D-5888-WTSA Report to the US EPA.

17. Madronich S. UV radiation in the natural and perturbed atmosphere. In: Tevini M, editor. Environmental effects of ultraviolet radiation. Boca Raton: Lewis Publisher; 1993. p. 17-69.

18. Perrin JM, Thuillier G, Fehrenbach M, Huppert F. A comparison between radiative transfer calculation and pyranometer dana gathered at Observatoire de Haute Provence. J Atmos Solar-Terres Phys 2005;67:44963.

19. Salum GM, Piacentini RD, Cede A, Luccini E, Marraco $\mathrm{H}$, Machado ME. Improving the CONAE solar UV index for Argentina. In: Wimmer Schweingruber R, editor. 
Proceedings of the 35th COSPAR Scientific Assembly; 18-25 July 2004; Paris, France. Paris: COSPAR; 2004. p. 3025.

20. Krzyscin JW, Jarosławski J, Sobolewski P. On an improvement of UV index forecast: UV index diagnosis and forecast for Belsk, Poland, in Spring/Summer 1999. J Atmos Solar-Terres Phys 2001;63:1593-600.

21. Andreson GP, Clough SA, Kneizys FX, Chetwynd JH, Shettle EP. AFGL atmospheric constituent profiles (0-120 km). Technical report AFGL-TR-86-0110, Air Force Geophysical Laboratory, 1986.

22. Elterman L. UV, visible and IR attenuation for altitudes to 50 km. Environ Res Papers 1968;285:49.

23. Lisac I, Vujnović V. Prorjeđivanje ozonosfere općenito i iznad Hrvatske - sadašnje stanje [Depletion of the ozonosphere globaly and above Croatia - present state, in Croatian]. Lošinjska škola 2005, Veli lošinj.
24. Lisac I, Vujnović V. Prilog poznavanju odnosa između ukupnog ozona i Sunčevog UVE zračenja u Hrvatskoj [A contribution to the study of total ozone over Croatia and corresponding UVE radiation, in Croatian]. In: Ivanišević G, editor. Zbornik radova sa skupa Zdravstveni turizam i vrednovanje prirodnih ljekovitih činitelja; 6-8 Sept 2002; Veli Lošinj. Zagreb: AMZH; 2002. p. 165-70.

25. National Aeronautics and Space Administration (NASA). Total ozone mapping spectrometer [displayed 30 April 2007]. Available at http://toms.gsfc.nasa. gov/ozone/ozone_v8.html

26. Micheletti MI, Piacentini RD, Madronich S. Sensitivity of biologically active UV radiation to stratospheric ozone changes: effects of action spectrum shape. Photochem Photobiol 2003; 78:456-61. 


\section{Sažetak}

\section{PROCJENA IZLOŽENOSTI UV ZRAČENJU TIJEKOM LJETNIH MJESECI U HRVATSKOJ S POMOĆU JEDNOSTAVNE PRIBLIŽNE FORMULE}

Tropospheric Ultraviolet-Visible (TUV) model, verzija 4.2 autora S. Madronicha (2003.) upotrijebljen je za procjenu izloženosti ultraljubičastom (UV) zračenju stanovništva u Hrvatskoj. Podnevne vrijednosti (13 h prema lokalnom vremenu) ultraljubičastog indeksa (UVI) izračunane su za 61 mjesto u Hrvatskoj za razdoblje travanj - listopad. Rezultati pokazuju da je u $13 \mathrm{~h}$ prema lokalnom vremenu rizik od nastanka opeklina izazvanih sunčevim zračenjem u danima bez naoblake visok između travnja i rujna (UVI $>7$ ) te da je rizik vrlo visok tijekom srpnja (UVI >10). U srpnju tijekom dana UV indeks prelazi viijednost 8 između $11 \mathrm{~h} \mathrm{i}$ $15 \mathrm{~h}$ prema lokalnom vremenu. U ovom radu za procjenu UV indeksa razvijena je jednostavna približna formula. Formula omogućava procjenu UV indeksa na temelju podataka o datumu, satu, nadmorskoj visini i naoblaci. Prilikom usporedbe rezultata dobivenih formulom i točnih rezultata dobivenih TUV modelom za ljetne mjesece lipanj, srpanj $\mathrm{i}$ kolovoz te razdoblje od $10 \mathrm{~h}$ do $16 \mathrm{~h}$ među rezultatima dobivena je razlika manja od $10 \%$.

KLJUČNE RIJEČI: geografski položaj, jadranska obala, nadmorska visina, Tropospheric Ultraviolet Visible model, UV indeks

\section{CORRESPONDING AUTHOR:}

\section{Gordana Pehnec}

Institute for Medical Research and Occupational Health Ksaverska cesta 2, 10000 Zagreb, Croatia

E-mail:gpehnec@imi.hr 